\title{
IX COLÓQUIO INTERNACIONAL DE GEOCRÍTICA: LOS PROBLE- MAS DEL MUNDO ACTUAL: SOLUCIONES Y ALTERNATIVAS DESDE LA GEOGRAFIA Y LAS CIENCIAS SOCIALES
}

\author{
Glória da Anunciação Alves*
}

\begin{abstract}
A proposta do IX Colóquio Internacional de Geocrítica, foi pautada no pressuposto de que tanto na ciência geográfica como nas demais ciências sociais, são feitos diagnósticos e muitas vezes se chegam às causas dos problemas, mas que era o momento de se procurar dar respostas e alternativas de soluções aos mesmos. Foi com esse espírito que o encontro, que tinha como título "Los problemas del mundo actual: soluciones y alternativas desde la Geografía y las Ciencias sociales" foi realizado, tendo como diretores os professores doutores Horacio Capel e Paulo Roberto Rodrigues Soares. Como organizadora geral do encontro tivemos a professora Doutora Vanda Ueda, que viria a falecer em 18 de julho de 2007 em um trágico acidente aéreo ocorrido em São Paulo.
\end{abstract}

Pode-se afirmar que se tratava de um encontro pequeno ${ }^{1}$, se comparado aos encontros de Geografia realizados no Brasil ${ }^{2}$ e na América Latina ${ }^{3}$, ainda que nele não houvesse taxa de inscrição. Durante cinco dias, de 28 de maio a $1^{\circ}$ de junho de 2007 na cidade de Porto Alegre, foram realizadas vinte e uma mesas, sendo que nenhuma delas foi concomitante, o que permitiu que todos os participantes pudessem acompanhar a todas as apresentações dos trabalhos e debates, devendo-se ainda ressaltar que todos os trabalhos já se encontravam disponibilizados na página do evento ${ }^{4}$ quando do início do encontro, o que, em teoria, possibilitaria um maior aprofundamento das questões propostas.
Os temas das mesas foram diversificados, podendo ser citados alguns como: questões teóricas e de método; as novas formas de segregação sócio-espacial; o planejamento urbano e as formas de participação; a questão da habitação; a questão agrária; do patrimônio histórico; o devir; migrações; questões ambientais; questões metropolitanas; redes; turismo; educação; multiculturalidade, cidadania, entre outros. Essa multiplicidade propiciou o pensar e refletir sobre a diversidade apresentada pelas pesquisas realizadas pelos participantes nacionais (de norte a sul do país) e internacionais (América Latina e Europa).

Dar conta de tantas temáticas e possibilitar que todos participassem das mais variadas seções, exigiu que os trabalhos, num total de cento e trinta ao longo do colóquio, fossem realizados em seções sucessivas, iniciadas pela manhã e terminadas à noite, sendo visível ao final do colóquio o cansaço daqueles que se envolveram nas diversas atividades.

De modo geral, as mesas foram bastante concorridas e possibilitaram debates, alguns deles calorosos, ainda que o tempo destinado aos mesmos fosse pequeno frente ao tempo de exposição das idéias dos proponentes. Em parte, os debates continuavam em outras ocasiões, como durante os almoços, jantares e cafés, além de outros momentos formais como o trabalho de campo realizado no centro de Porto Alegre no sábado, dia 2 de junho, após o 
encerramento formal das atividades do evento.

O professor Jorge Gaspar, da Universidade de Lisboa, foi homenageado, recebendo o Premio Geocrítica Internacional. Na ocasião dessa solenidade, o professor Gaspar proferiu uma fala sobre sua trajetória acadêmica, ressaltando os intelectuais que foram importantes em sua formação bem como os que com ele trabalharam e propiciaram um posicionamento enquanto profissional.

A abertura desse que foi um colóquio marcado por uma intensa discussão acadêmica, ficou a cargo do professor Horácio Capel, que, com sua fala intitulada "Las ciencias sociales en la solución de los problemas del mundo actual", destacou a proposta geral do evento. Também no encerramento, o referido professor fez uma breve avaliação do colóquio e ressaltou o papel da Geografia no atual contexto de crises globalizadas e locais. Ainda nessa mesa de encerramento, o professor Capel anunciou a realização do X Colóquio Internacional de Geocrítica, a ser realizado em Barcelona (Espanha) de 26 a 30 de maio de 2008, colóquio este intitulado "Diez años de cambio en el mundo, en la geografía y en las ciencias sociales, 1999-2008".

Podemos afirmar que se tratou de um colóquio que proporcionou um importante debate acadêmico-científico, bem como a possibilidade de maior interação entre pesquisadores brasileiros, latino-americanos e europeus, frente às questões postas no mundo atual em uma perspectiva crítica.

\section{Notas}

1 Entre expositores e participantes assistentes, havia no encontro cerca de duzentos e cinqüenta pessoas. Vale ressaltar que boa parte dos assistentes eram alunos do curso de Geografia da Universidade Federal do Rio Grande do Sul (UFRG) em Porto Alegre.

2 Encontros como ENG (Encontro Nacional de Geógrafos) e Fala Professor, organizados pela AGB (Associação dos Geógrafos Brasileiros), contam, em geral, com mais de mil participantes.
3 Como exemplo podemos citar o EGAL .

4 http://www.ub.es/geocrit/9porto/progse.htm. Os trabalhos passaram por avaliação e os aprovados para publicação ficam disponibilizados na página da Geocrítica, http://www.ub.es/geocrit/nova.htm ou http:/ Lwww.ub.es/geocrit/sn/sn-245.htm.

Trabalho enviado em agosto de 2007

Trabalho aceito em setembro de 2007 